Levytska S. 0. [1; ORCID ID: 0000-0002-4739-0486], Doctor of Economics, Professor

${ }^{1}$ National University of Water and Environmental Engineering, Rivne

\title{
ECONOMIC BENEFIT ASSESSMENT FOR ASSETS IN TRANSACTIONS OF SOCIALLY RESPONSIBLE BUSINESS
}

\begin{abstract}
Alternative forms of economic benefit from production using resources based on the results of domestic enterprises transactions in the context of the policy of balanced business conduct are studied. The international practice of financial results determining for entities that based on analytical accounting of economic benefit elements assessment, taking into account their impact on economic development, social protection and environmental security both at the entity level and macro level is generalized. Criteria for assessing economic and socio-economic benefit, social effect are specified. Methodical and practical approaches to economic benefit classification as an object of accounting and management are proposed.
\end{abstract}

Keywords: economic benefit; potential of utility; enterprise; social responsibility; transaction; business balanced; integrated accounting system.

Formulation of the problem. Doing business on the basis of socioeconomic and environmental balance determines the specific approaches to the modern management organization, accounting facilities development and the harmonization of integrated financial accounting system for domestic enterprises of all ownership forms. The latter, in turn, requires the objectivity of professional judgment substantiation for the choice of alternative methods both accounting and value calculating of assets, the introduction of integrated reporting with using financial and non-financial indicators.

Enterprises from countries that pay due attention to improving business regulatory framework, the security of property rights, the motivational system formation of bank lending for the implementation of both innovation and national social programs adapt to international markets better. Economic freedom institutional and political platforms that is focused on a market economy produce a wide range of opportunities for business development in practice.

So-called «a priori (determined by public and state economic development interests) entrepreneurship» is more successful because it arises voluntarily, receives community support, realizes opportunities 
in order to attract innovative resources, develops new markets, etc. [1].

Some public policy instruments such as corruption control, political and economic stability, business support contribute to the positive impact of entrepreneurship for national economic growth.

The modern view of inequality of consumption by social groups without a deep economic development correlation analysis leads to faulty statements: scientists and economists-practitioners erroneously claim that individual inequality is primarily the result of anomalous benefits from «individual creative destructions» manifestations. As a result, the issue of social injustice (economic inequality) is not linked to market processes. So the economic imbalances detection does not lead to a corrective business development policy [2].

Balance and entrepreneurship are often seen as binary concepts that have a commercial relationship, such as: financial security of socioenvironmental programs higher-commercial interests of the subject narrower; economic benefits lower [3].

We have some definitions of «balanced» today. English original of «sustainable development» means «supported development». The French version of this term is quite interesting - «development durable» that means strong / long development [4]. The most concept «balanced (sustainable) development» interpretation that could be adapted to economic realities is generalized as establishing a balance between meeting modern human needs and protecting future generations interests, including a safe and healthy environment [5].

Thus, it is common for domestic business to understand the «business balanced» through a comprehensive system of implementation positive dynamics of economic activity main indicators, the realization both of social support realization for workers and environmental safety measures [6].

An important reason for studying entrepreneurship is its recognition as a direct influence factor on growth and development processes. The knowledge-based entrepreneurship has a greater impact on the economic growth than other entrepreneurship types without a knowledge base (it has been proven in practice). A comprehensive study and potential economic opportunities assessment are important for prioritizing business-related management strategies in terms of long-term growth. At the same time, entrepreneurial activity motivated only by needs solves short-term problems without having an impact on long-term economic growth [7].

Unfortunately, Ukrainian economy is characterized by the alarming socio-economic indicators dynamic currently. According to the results of January-March 2020, in our country regions there were 
negative trends of the production dynamic in key areas of development, in particular: industrial production decreased by $5.1 \%$ (in JanuaryMarch 2019 there was a decrease of $0.1 \%$ ). Negative dynamics in terms of agricultural output gross was a decrease of $1.8 \%$ (an increase of $3.4 \%$ we had in the corresponding period of 2019). The situation in the consumer market was characterized by rising prices in March 2020 , compared to December 2019 in all regions [8].

Concern about both company economic benefits, as a participant in the modern market, and the reliability of such an assessment led to the clarify need to the entrepreneurship essence: the entrepreneurship is seen as a mechanism for adapting to change. Scientists and practitioners about benefits of entrepreneurship are unanimous: the evaluation of business should reflect not only economic but also social, limited by time and place, elements [9].

The combination of business profitability criteria, its integration with regional programs of both socio-economic development and environmental security has led to a new term - «business ecosystem», which is considered as a set of production resources involved in socially important economic tasks.

The definition of «business ecosystem» is the reforming result of the term «social enterprise» to sustainable business development needs. The concept of «social entrepreneurship» as a comprehensive socio-economic problems solution, that is based on maximizing benefits and minimizing the negative their activities consequences [10] was clarified by the mission of environment preserving.

Today, research focuses on the both creation, management and business ecosystems sustainability, mechanism of rational distribution study of value added for economic, technological and social benefits. Therefore, accounting tools for received (or lost) economic benefit assessing, accounting and analytical support of those transactions are important [11].

Factors influencing on economic benefits assessment for production resources used in transactions need to be clarified. Thus, the social entrepreneurship role is important in order to generalize of its through the social component assessment of value added for entrepreneurial activity, which is aimed at ensuring:

- business results integration with region programs and plans in order to achieve progress;

- systematic control over the adverse effects reduction of entrepreneurial activity;

- providing business of applied scientific support;

- regional / state social multiplier implementation for 
entrepreneurship;

- economic support of socio-economic and environmental performance indicators for balanced business [12].

Analysis of recent research and publications. The methodology and organization of economic benefit, potential of utility for enterprises transactions in the context of the balanced business policy, measurement of benefit were presented in the scientific works of many Ukrainian and foreign scholars, such as: Z. Zadorozhnyi, V. Yasyshena [16], L. Ukrainian [17], A. Kostiakova [31], O. Fomina [32], Packard M. D., Bylund P. L. [2], R. S. Aquino, M Lück, H A. Schänzel [10], Shaker A. Zahra and Mike Wright [12] et al.

Concepts of the modern market development enhance the business performance assessment through its impact on the social security and environmental safety programs implementation at both the enterprise level and regional level.

Assessment of socio-economic and environmental areas of balanced business, accounting and analytical support of transactions that form calculated indicators, their control require further research.

Objectives of the article are: generalization of factors influencing the formation of assets and economic benefits of them in enterprises transactions taking into account requirements for socioeconomic and environmental balance of business; justification of both methodological and organizational approaches and variable forms of economic benefit identification, its evaluation, accounting and analytical support.

Main outcomes of the study. The source of economic benefits (EB) assessment in socially responsible business transactions is a wide factors ranges, in particular: systemic management policy on the principles of balanced use of productive resources; ensuring marketing activities effectiveness; transactions of the enterprise within the framework of programs of social workers and community as a whole protection, ecological safety of the environment; knowledge of market competition, innovative technical knowledge, etc.

$E B$, as a basis for the book value of a production asset has documentary support (namely, reliability assessment). The company controls liquidity processes of assets preliminary assessments and has the authority for manage such assets, that ensures expected economic benefits preservation of they, in particular: knowledge are legally protected, trade agreements rights are governed by license restrictions, employees have legal obligations not to disclose of 
confidential information (point 14 of IFRS 38) [13].

The sequence of formation stages and EB implementation:

I. Transactions, as a result of which assets are accounted (acquisition, creation, free receipt, exchange). The enterprise determines EB at the asset original cost.

II. The control over assets that the enterprise received.

III. The realization of EB: sale, exchange for other assets, use for production needs, own consumption. As a result of which liquid coverage of EB is provided, or they write-off as expenses. The enterprise determines the maximum economic benefit at this stage that is available due to cash or other compensatory income, reductions expenses in the future, or a combination of these options [14].

If the economic component of the EB is formed on the basis of the costs incurred in accounting or keeping their on the balance sheet, the social component requires the more attention in order to substantiate professional judgment. It is important to make sure of the following, whether: identification of the social component of economic benefit is appropriate and necessary; the certain social program legal support is valid; the acceptable level of its effective implementation risk may be, etc.

The economic benefit social component is designed to meet needs of society as a whole. Thus, IPSASB note that social benefit is provided where the social risk is (for example, a person has become unemployed or reached retirement age). At the same time, social risks do not involve of obligations by the beneficiary (in particular, in terms of those benefit return). Therefore, the commitment approach will not be appropriate for recognizing and measuring social benefits [15].

The investigation of EB (its transformation) in socially responsible business transactions would be illustratively on the example of intangible assets (IA). Economists have identified intangible assets as key positions of the world economy development. It is established that 500 joint-stock companies in the United States with the largest market capitalization have changed the share of intangible assets during in 40 years. As a result, the IA share increased from $17 \%$ to $84 \%$. Intangible assets are the main sustainable value creation source, because they open up certain benefits that could be used in foreign markets, encourage firms to geographically diversify [16].

Economic, legal, accounting and valuation approaches difference in IA nature understanding. So, we have a gap between the accounting methodology and the current obtaining needs for 
objectivity of strategic accounting information. Researchers recommend considering IA as identified and valued long-term and current assets that have not physically embodied, such as: intellectual property rights, natural resources using, and so on, that could bring economic benefits. At the same time, attention is seldom focused on: the enterprise control and management in respect of such assets, the liquidity value determination, physical depreciation assessment and depreciation risk, compliance with requirements in accordance of accounting standards etc.

Methodological approaches to use certain IA assessing, such as «Intellectual Property» (human capital) are interesting given the importance of balance maintaining of socio-economic and environmental business components. In the interpretation of the category «Intellectual Property» essence such assets are considered in two parts: the acquired professional abilities of a person and results of his activities. Accordingly, the book value for those IA is affected by two components of EB:

- cost: assessment of the costs reproduction for the professional competencies formation of the employee;

- quality: professional judgment of management on the expected potential usefulness from his work [17].

It is important to take into account that the method of such intangible assets valuation is the continuous process.

Their using does not imply the end of book value formation. Human capital productive use is characterized by a permanent profitability increase for both the employee and the entity. Therefore, increasing costs of both productive qualities and employee characteristics could be considered as an investment.

Business management needs objective information about asset liquidity in order to make operational and strategic management decisions. Given the period of accounting assessment transformation of the EB (its coverage by financial flows or other compensation forms) is necessary to identify them by analytical sub-accounts obtained economic benefits and potential economic benefits.

The potential of utility and the potential economic benefit are often wrongly identified. Results of a potential economic benefits are transactions which give for the enterprise funds from such assets realization (or using) during next periods. If we have the direct impact of such an asset on sales transactions (for example, depreciation of property, plant and equipment), the potential of utility is obvious.

In the public sector of Ukraine entities define «potential of utility» as the available and potential opportunities that entities will receive 
from non-cash-generating assets using in order to achieve a goal or meet needs of their economic activity [18].

Let consider the company «Airbnb», which operates in the Internet market for short-term rental housing, for example. At a broad level, the Airbnb potential economic benefits and costs are relatively simple. The main potential benefit is that property owners can diversify the potential income streams that they receive from home ownership. Another potential advantages are increase both supply and varieties of shortterm leases, which will avoid rising prices for short-term leases.

The biggest potential benefits of Airbnb is the higher cost of housing for city residents which provided by a sufficient number of properties transferred from long-term to short-term lease. Such additional amounts are charged to tenants as external consequences compensation (noise, negative impact on property safety, etc.) [19].

Balanced entrepreneurship is often viewed with the concept of «ecosystem». This metaphor is used to replace the traditional term «markets». Such multi-productive combinations do not operate with standard market economy theories, such as existing markets structures with existing barriers to entry and exit (almost not adapted to today's markets competition rules).

The entrepreneurial ecosystem must fulfill definite certain tasks: to create ecosystem value and to value distribute among members of the ecosystem (Clarysse et al. 2014; Stephen et al. 2012; Vargo and Lusch 2010). These postulates are the modern view basis for business competitiveness. Social benefits are designed to ensure the supply of new products and services that benefit society [20].

Among defining indicators for the business ecosystem subject is the consideration of value added assessment components in the «mixed value» that created by this business. International business practice in economic benefits assessing operates with a philosophy of «mixed value» as one of tools in order to both assess business economic potential and creat financial, social and environmental value for society and the economy at whole. «Mixed value» implies compromises between commercial and social aspects. Therefore, it actualizes the business sustainability, that directly depends on favorable tax regimes, other state support forms. This leads to the appropriate level of analytical accounting introduction, which is quite acceptable, as an option, as the managerial accounting. Managerial accounting nowadays is the accounting system of transactions with analytical reflection of important indicators identified by managers [21; 22]. 
National and international accounting standards are generally consistent with each other in estimating income (expenses) criteria through the economic benefits recognition. However, the definition of income (expenses) according to national accounting standards as «receipt (disposal) of assets or reduction (increase) of liabilities» is criticized by scientists.

The receipt of economic benefits assessment for enterprise depends on the transaction nature, in particular:

- assets purchased for business activities will ensure the funds receipt for the enterprise as a result of the goods sale (of works, services);

- financial investments in stocks, bonds, deposits allow cash flow go on to the company in the form of interest, dividends, etc.;

- receivables is a direct receipt of funds (inventory) as a result of its debtor's repayments or receipt of money in a bank account from factoring transactions.

Indirect funds inflowln could be in the each of these transactions through the implementation of non-cash transactions, payment of dividends, repayment of liabilities by tangible assets, in particular.

Taking into account international accounting practice, domestic development the EB can be both in tangible and intangible form through business popularization, creation of its positive image, etc. Approaches unification for the interpretation of economic benefits and indicators of its evaluation in domestic enterprises activities wants better (Table).

Table

Economic benefit forms in transactions of socially responsible business [23]

\begin{tabular}{|c|c|c|c|c|c|}
\hline \multirow[b]{2}{*}{ \# } & \multirow[t]{2}{*}{ Income determination } & \multicolumn{4}{|c|}{ Economic benefit assessing criteria } \\
\hline & & $\begin{array}{l}\text { value of } \\
\text { tangible } \\
\text { and } \\
\text { intangible } \\
\text { assets }\end{array}$ & $\begin{array}{l}\text { the } \\
\text { money } \\
\text { amount }\end{array}$ & $\begin{array}{l}\text { busines } \\
\text { s image }\end{array}$ & $\begin{array}{l}\text { social } \\
\text { effect }\end{array}$ \\
\hline 1 & 2 & 3 & 4 & 5 & 6 \\
\hline & \multicolumn{5}{|c|}{ normative definition } \\
\hline 1 & $\begin{array}{l}\text { NAR(S)15 «Revenue» [24]: } \\
\text { Assets increase or liabilities } \\
\text { decrease that results in an } \\
\text { increase in equity (other than } \\
\text { an increase in equity due to } \\
\text { contributions from enterprise } \\
\text { members/owners), provided } \\
\text { that the income estimate can } \\
\text { be measured reliably }\end{array}$ & $V$ & V & & \\
\hline
\end{tabular}




\begin{tabular}{|c|c|c|c|c|c|}
\hline 2 & $\begin{array}{l}\text { Tax Code of Ukraine [25]: } \\
\text { The total taxpayer income } \\
\text { amount from all activities } \\
\text { types that received (accrued) } \\
\text { during the reporting period } \\
\text { in monetary, tangible or } \\
\text { intangible forms on the } \\
\text { territory of Ukraine, its } \\
\text { continental shelf in the } \\
\text { exclusive (maritime) } \\
\text { economic zone or outside } \\
\text { them }\end{array}$ & v & $\mathrm{V}$ & & \\
\hline 3 & $\begin{array}{l}\quad \text { IPSAS } 1 \text { «Presentation of } \\
\text { Financial Statements» [26]: } \\
\text { Gross economic benefits or } \\
\text { service potential receipts } \\
\text { during the reporting period, } \\
\text { when net assets / equity } \\
\text { increase as a result of these } \\
\text { receipts but not as a result of } \\
\text { owners' contributions }\end{array}$ & $\mathrm{V}$ & 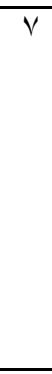 & & $\mathrm{V}$ \\
\hline & \multicolumn{5}{|c|}{ economic content } \\
\hline 4 & \begin{tabular}{l}
\multicolumn{1}{c}{ Economic explanatory } \\
dictionary [27]:Money or \\
tangible assets received from \\
both production, commercial, \\
intermediary and other \\
activities
\end{tabular} & $\mathrm{V}$ & V & $\mathrm{V}$ & \\
\hline 5 & $\begin{array}{l}\text { Economic encyclopedia [28]: } \\
\text { The difference between } \\
\text { revenue from sales of } \\
\text { products, works or services } \\
\text { and the cost of material } \\
\text { production or sale costs for } \\
\text { these products }\end{array}$ & v & v & & \\
\hline & \multicolumn{5}{|c|}{ scientific and journalistic approaches } \\
\hline 6 & $\begin{array}{l}\text { Nashkerska GV Accounting / } \\
\text { Tutorial [29]: The expected } \\
\text { object property, which is the } \\
\text { motive for the creation, } \\
\text { production, ownership, use of } \\
\text { this object }\end{array}$ & $\mathrm{V}$ & V & V & $\mathrm{V}$ \\
\hline 7 & \begin{tabular}{l}
\multicolumn{1}{c}{ Primak TO Business } \\
Economics / Tutorial [30]: \\
Financial ratio, which is \\
defined as the difference \\
between business activities \\
proceeds and material costs \\
(including equated to them \\
costs)
\end{tabular} & $\mathrm{V}$ & V & & \\
\hline
\end{tabular}


Not every assets increase and liabilities decrease characterizes the income receipt time. This applies to advance payments from buyerins, particular. Assets increase will be income recognized as a result of supply agreement fulfilling terms.

Taking into account the transformation period of the EB assessment into funds or other compensation forms, it is advisable to analytical subaccounts introduce in the accounting activities practice. The strategic management accounting international practice is interesting, because the analytical level identifies the EB depending on its receipt period:

- potential of utility: the economic benefits assessment of the asset that the enterprise plans for using to transactions in future (for example, a license for a particular activity, production of fixed assets, etc.). Those assets don't bring funds directly, but they provide the receipt of EB;

- future economic benefit: economic benefit assessment of the asset as a performed transaction result, which will be a highly liquid asset in subsequent reporting periods (for example, trade receivables);

- implemented economic benefit: the economic benefit assessment of the asset, confirmed by the actual receipt of funds or other highly liquid assets [31; 32].

By the nature of transactions impact on social, economic and environmental issues, EB forms could be analytically accounted by types:

- economic benefits: benefits of production assets that intended for financial and economic transactions support of enterprise statutory activities;

- socio-economic benefit: benefits of assets intended for use at social programs, public non-profit organizations support, etc.;

- social effect: the benefit, assessed by qualitative parameters, obtained by the company in transactions on a charitable basis, which increases the social attractiveness of this company.

The use of above EB classification in accounting will improve the accounting and analytical information reliability for managers in order to make effective operational and strategic decisions by them.

Conclusions. The entrepreneurial activity development in Ukraine, active new types of competitive products search to position their capabilities in international markets determine businesses needs the technical innovations introduction, new financial sources attraction and innovative support at whole. The enterprise management is based not only on financial reporting data, but on reliable accounting and analytical financial results support too. In turn, the "economic benefit" 
concept as a basis for estimating income and expenses requires clarification of its evaluation criteria and sufficient analytics. Taking into account social responsibility requirements, compliance with environmental safety principles of production activities consequences, economic benefit as an accounting object demands the recognition of both financial and non-financial assessment.

The article summarizes the international practice of reflecting economic benefit that offers an analytical format for reflecting the economic benefit assessment by the criteria of:

- the its receipt period: potential of utility, future economic benefit, implemented economic benefit;

- the transactions nature of its impact on social, economic and environmental issues: economic benefit, social-economic benefit, social effect.

Assessment publication in the reporting (in the Notes as additional information, or in the Integrated Reporting, that is not yet state regulated) will improve effectiveness of enterprise management, confidence of both investors and employees to the usefulness of the business.

1. María J. Angulo-Guerrero, Salvador Pérez-Moreno. How economic freedom affects opportunity and necessity entrepreneurship in the OECD countries. Journal of Business Research. 2017. 73. P. 30-37. URL: http://isidl.com/wpcontent/uploads/2017/06/E4190-ISIDL.pdf. (accessed: 22.08.2020). 2. Packard M. D., Bylund P. L. On the relationship between inequality and entrepreneurship. Strategic Entrepreneurship Journal. 2017. P. 1-20. DOI. org/10.1002/sej.1270. 3. Chang Soo Sung and Joo Y. Park. Sustainability Orientation and Entrepreneurship Orientation: Is There a Tradeoff Relationship between Them? Sustainability. 2018, 10, 379. DOI:10.3390/su10020379. 4. Апостолюк С. О. Промислова екологія : навч. посіб. К. : Знання, 2012. 430 с. 5. Сталий розвиток. Wikipedia. URL: http://uk.wikipedia.org/wiki (дата звернення: 16.09.2020). 6. Svitlana Levytska, Olga Osadcha. Sustainable regional economics as result of administrative-territorial reform in Ukrain: accounting and managerial approaches. International Journal of New Economics and Social Sciences (IJONESS). № 1 (3). 2016. P. 200-206. URL: http://www.ijoness.esy.es/pl (accessed: 22.08.2020). 7. Aparicio S. and Urbano D. and Audretsch D. 'Institutional factors, opportunity entrepreneurship and economic growth: panel data evidence. Technological forecasting and social change. 2016. 102 . P. 45-61. DOl:org/10.1016/j.techfore.2015.04.006. 8. Аналіз стану соціально-економічного розвитку областей та міста Києва за січень-березень 2020 року. Міністерство розвитку громад та територій України. URL: https://www.minregion.gov.ua/napryamki-diyalnosti/regional-dev/derzhavnarehional-na-polityka/monitorynh (дата звернення: 16.09.2020). 9. Alistair R. Anderson. Conceptualising Entrepreneurship as Economic «Explanation» and the Consequent Loss of «Understanding». International Journal of Business and Globalisation. 2015. 14 (2). P. 145-157. DOI: 10.1504/IJBG.2015.06743. 10. R. S. Aquino, M. Lück, H. A. Schänzel. A conceptual framework of tourism social 
Серія «Економічні науки»

Випуск 3(91) 2020 р.

entrepreneurship for sustainable community development. Journal of Hospitality and Tourism Management.

URL:

https://www.sciencedirect.com/science/article/abs/pii/S1447677018300925

(accessed: 22.08.2020). 11. David B. Audretsch, James A. Cunningham, Donald F. Kuratko, Erik E. Lehmann, Matthias Menter. Entrepreneurial ecosystems: economic, technological, and societal impacts. The Journal of Technology Transfer. 2019. 44. P. 313-325. DOl:org/10.1007/s10961-018-9690-4. 12. Shaker A. Zahra and Mike Wright. Understanding the Social Role of Entrepreneurship. Journal of Management Studies. 53:4. June 2016. P. 610-629. DOI: org/10.1111/joms. 12149. 13. MCБ0 -IAS 38 «Нематеріальні активи». URL: https://zakon.help/article/msbo-38-nematerialniaktivi-msbo-38-nematerialni (дата звернення: 16.09.2020). 14. Тлумачення КТМФЗ 14 МСБО 19: Обмеження на активи з визначеною виплатою, мінімальні вимоги до фінансування та їхня взаємодія. IFRIC 14_ukr.pdf. URL: https://zakon.help/article/tlumachennya-ktmfz-14-msbo-19-obmezhennya-na-aktivizа (дата звернення: 16.09.2020). 15. International Public Sector Accounting Standards Board (IPSASB) 42 Summary-Social Benefits. URL: https://www.ifac.org/system/files/publications/files/IPSAS-42-Social-Benefits-At-aGlance.pdf (accessed: 22.08.2020). 16. Zenovii-Mykhailo Zadorozhnyi, Valentyna Yasyshena. Intangible assets as an accounting and management object. Marketing and Management of Innovations. Issue1. 2019. DOl:org/10.21272/mmi.2019.1-10. 17. Українська Л. О. Людський капітал корпорації: сучасні особливості формування. Економічна теорія і право : зб. наук. праць. Харків : Право, 2018. № 2 (33). DOI: 10.31359/2411-5584-2018-33-2-42. 18. НПСБОДС 121 «Основні засоби» : наказ МФУ № 1202 від 12.10.2010. Документ z1017-10. Редакція від 01.01.2018, підстава-z1546-17. URL: https://zakon.rada.gov.ua/laws/show/z1017-10\#Text (дата звернення: 16.09.2020). 19. The economic costs and benefits of Airbnb : Report By Josh Bivens. January 30, 2019. URL: https://www.epi.org/publication/the-economic-costs-and-benefits-ofairbnb-no-reason-for-local-policymakers-to-let-airbnb-bypass-tax-or-regulatoryobligations. (accessed: 22.08.2020). 20. David B. Audretsch, James A. Cunningham, Donald F. Kuratko, Erik E. Lehmann, Matthias Menter. Entrepreneurial ecosystems: economic, technological, and societal impacts. The Journal of Technology Transfer. 2019. 44. P. 313-325. DOI:org/10.1007/s10961-018-9690-4. 21. Coman Dan Marius, Coman Mihaela Denisa, Boca (Rakos) Ileana Florina. Managerial accounting as the source of information for an efficient management in SME. DOI:10.1016/j.sbspro.2012.09.085. 22. Neil's Brock Copenhagen Business College. Kultorvet 2, Copenhagen K, Denmark, 2008. 250 р. 23. Левицька С. О., Осадча О. 0. Економічна вигода як оцінка доходу в бухгалтерському обліку: методичні та організаційні підходи визнання. Бухгалтерський облік і аудит : науково-практичний журнал. № 5. 2013. С. 20-28. 24. Положення (стандарт) бухгалтерського обліку 15 «Дохід»: наказ Міністерства фінансів України від 29 листопада 1999 року № 290 (з чинними змінами і доповненнями). URL: https://zakon.help/law/z0860-99] (дата звернення: 16.09.2020). 25. Податковий кодекс України : № 2755-VI від 02.12.2010 p. (з чинними змінами д доповненнями). URL: https://zakon.rada.gov.ua/laws/show/2755-17\#Text. (дата звернення: 16.09.2020). 26. МСБОДС 1 «Подання звітів». URL: https://buhgalter911.com/public/uploads/normativka/Standart_gossektor/\%D0\%9C\% D0\%A1\%D0\%91\%D0\%9E\%D0\%94\%D0\%A1/\%D0\%9C\%D0\%A1\%D0\%91\%D0\%9E\%D0\%9 4\%D0\%A1_1.pdf (дата звернення: 16.09.2020). 27. Алексеєнко Л. М., Олексієнко В. М. Економічний тлумачний словник : власність, приватизація, ринок 
цінних паперів (українсько-англійсько-російський). Тернопіль: Астон, 2003. 672 с. 28. Економічна енциклопедія : у 3-х томах. Київ : Видавничий центр «Академія», 2000. Т. 1. 864 с. 29. Нашкерська Г. В. Бухгалтерський облік : навч. посібник. К. : Центр навчальної літератури, 2004. 464 с. 30. Примак Т. О. Економіка підприємства : навч. посіб. 5-те вид., стер. К. : Вікар, 2008. 219 с. 31. Костякова А. А. Стратегічний управлінський облік: сутність та поняття. Причорноморські економічні студії. 2019. Вип. 39(2). С. 99-102. URL: http://nbuv.gov.ua/UJRN/bses_2019_39\%282\%29_21 (дата звернення: 16.09.2020). 32. Фоміна О. В. Управлінський облік у торгівлі : монографія. Київ. нац. торг.екон. ун-т, 2016. 468 с. URL: https://knute.edu.ua/file/MjExMzA=/624a6d7d9a739851810eef1d42fb84ce.pdf (дата звернення: 16.09.2020).

\section{REFERENCES:}

1. María J. Angulo-Guerrero, Salvador Pérez-Moreno. How economic freedom affects opportunity and necessity entrepreneurship in the OECD countries. Journal of Business Research. 2017. 73. P. 30-37. URL: http://isidl.com/wpcontent/uploads/2017/06/E4190-ISIDL.pdf (accessed: 22.08.2020). 2. Packard M. D., Bylund P. L. On the relationship between inequality and entrepreneurship. Strategic Entrepreneurship Journal. 2017. P. 1-20. DOI. org/10.1002/sej.1270. 3. Chang Soo Sung and Joo Y. Park. Sustainability Orientation and Entrepreneurship Orientation: Is There a Tradeoff Relationship between Them? Sustainability. 2018, 10, 379. DOI:10.3390/su10020379. 4. Apostoliuk C. O. Promyslova ekolohiia : navch. posib. K. : Znannia, 2012. 430 s. 5. Stalyi rozvytok. Wikipedia. URL: http://uk.wikipedia.org/wiki (data zvernennia: 16.09.2020). 6. Svitlana Levytska, Olga Osadcha. Sustainable regional economics as result of administrative-territorial reform in Ukrain: accounting and managerial approaches. International Journal of New Economics and Social Sciences (IJONESS). № 1 (3). 2016. P. 200-206. URL: http://www.ijoness.esy.es/pl (accessed: 22.08.2020). 7. Aparicio S. and Urbano D. and Audretsch D. Institutional factors, opportunity entrepreneurship and economic growth: panel data evidence. Technological forecasting and social change. 2016. 102 . P. 45-61. DOI:org/10.1016/j.techfore.2015.04.006. 8. Analiz stanu sotsialno-ekonomichnoho rozvytku oblastei ta mista Kyieva za sichen-berezen 2020 roku. Ministerstvo rozvytku hromad ta terytorii Ukrainy. URL: https://www.minregion.gov.ua/napryamkidiyalnosti/regional-dev/derzhavna-rehional-na-polityka/monitorynh (data zvernennia: 16.09.2020). 9. Alistair R. Anderson. Conceptualising Entrepreneurship as Economic "Explanation" and the Consequent Loss of "Understanding". International Journal of Business and Globalisation. 2015. 14 (2). P. 145-157. DOI: 10.1504/IJBG.2015.06743. 10. R. S. Aquino, M. Lück, H. A. Schänzel. A conceptual framework of tourism social entrepreneurship for sustainable community development. Journal of Hospitality and Tourism Management.

URL: https://www.sciencedirect.com/science/article/abs/pii/S1447677018300925 (accessed: 22.08.2020). 11. David B. Audretsch, James A. Cunningham, Donald F. Kuratko, Erik E. Lehmann, Matthias Menter. Entrepreneurial ecosystems: economic, technological, and societal impacts. The Journal of Technology Transfer. 2019. 44. P. 313-325. DOl:org/10.1007/s10961-018-9690-4. 12. Shaker A. Zahra and Mike Wright. Understanding the Social Role of Entrepreneurship. Journal of Management Studies. 53:4. June 2016. P. 610-629. DOI: org/10.1111/joms. 12149. 13. MSBO -IAS 38 «Nematerialni aktyvy». URL: https://zakon.help/article/msbo-38-nematerialni-aktivimsbo-38-nematerialni (data zvernennia: 16.09.2020). 14. Tlumachennia KTMFZ 14 
Серія «Економічні науки»

Випуск 3(91) 2020 р.

MSBO 19: Obmezhennia na aktyvy z vyznachenoiu vyplatoiu, minimalni vymohy do finansuvannia ta yikhnia vzaiemodiia. IFRIC 14_ukr.pdf. URL: https://zakon.help/article/tlumachennya-ktmfz-14-msbo-19-obmezhennya-na-aktiviza (data zvernennia: 16.09.2020). 15. International Public Sector Accounting Standards Board (IPSASB) 42 Summary-Social Benefits. URL: https://www.ifac.org/system/files/publications/files/IPSAS-42-Social-Benefits-At-aGlance.pdf (accessed: 22.08.2020). 16. Zenovii-Mykhailo Zadorozhnyi, Valentyna Yasyshena. Intangible assets as an accounting and management object. Marketing and Management of Innovations. Issue1. 2019. DOI:org/10.21272/mmi.2019.1-10. 17. Ukrainska L. O. Liudskyi kapital korporatsii: suchasni osoblyvosti formuvannia. Ekonomichna teoriia i pravo : zb. nauk. prats. Kharkiv : Pravo, 2018. № 2 (33). DOI: 10.31359/2411-5584-2018-33-2-42. 18. NPSBODS 121 «Osnovni zasoby»: nakaz MFU № 1202 vid 12.10.2010. Dokument z1017-10. Redaktsiia vid 01.01.2018, pidstavaz1546-17. URL: https://zakon.rada.gov.ua/laws/show/z1017-10\#Text (data zvernennia: 16.09.2020). 19. The economic costs and benefits of Airbnb : Report By Josh Bivens. January 30, 2019. URL: https://www.epi.org/publication/the-economiccosts-and-benefits-of-airbnb-no-reason-for-local-policymakers-to-let-airbnb-bypasstax-or-regulatory-obligations (accessed: 22.08.2020). 20. David B. Audretsch, James A. Cunningham, Donald F. Kuratko, Erik E. Lehmann, Matthias Menter. Entrepreneurial ecosystems: economic, technological, and societal impacts. The Journal of Technology Transfer. 2019. 44. P. 313-325. DOI:org/10.1007/s10961-018-9690-4. 21. Coman Dan Marius, Coman Mihaela Denisa, Boca (Rakos) Ileana Florina. Managerial accounting as the source of information for an efficient management in SME. DOI:10.1016/j.sbspro.2012.09.085. 22. Neils Brock Copenhagen Business College. Kultorvet 2, Copenhagen K, Denmark, 2008. 250 p. 23. Levytska S. 0., Osadcha 0. 0. Ekonomichna vyhoda yak otsinka dokhodu v bukhhalterskomu obliku: metodychni ta orhanizatsiini pidkhody vyznannia. Bukhhalterskyi oblik $i$ audyt : naukovo-praktychnyi zhurnal. № 5. 2013. S. 20-28. 24. Polozhennia (standart) bukhhalterskoho obliku 15 «Dokhid»: nakaz Ministerstva finansiv Ukrainy vid 29 lystopada 1999 roku № 290 (z chynnymy zminamy i dopovnenniamy). URL: https://zakon.help/law/z0860-99] (data zvernennia: 16.09.2020). 25. Podatkovyi kodeks Ukrainy : № 2755-VI vid 02.12.2010 r. (z chynnymy zminamy i dopovnenniamy). URL: https://zakon.rada.gov.ua/laws/show/2755-17\#Text. (data zvernennia: 16.09.2020). 26. MSBODS 1 «Podannia finansovykh zvitiv». URL: https://buhgalter911.com/public/uploads/normativka/Standart_gossektor/\%D0\%9C\% D0\%A1\%D0\%91\%D0\%9E\%D0\%94\%D0\%A1/\%D0\%9C\%D0\%A1\%D0\%91\%D0\%9E\%D0\%9 4\%D0\%A1_1.pdf (data zvernennia: 16.09.2020). 27. Alekseienko L. M., Oleksiienko V. M. Ekonomichnyi tlumachnyi slovnyk : vlasnist, pryvatyzatsiia, rynok tsinnykh paperiv (ukrainsko-anhliisko-rosiiskyi). Ternopil : Aston, 2003. 672 s. 28. Ekonomichna entsyklopediia : y 3-kh tomakh. Kyiv : Vydavnychyi tsentr «Akademiia», 2000. T. 1. 864 s. 29. Nashkerska H. V. Bukhhalterskyi oblik : navch. posibnyk. K. : Tsentr navchalnoi literatury, 2004. 464 s. 30. Prymak T. 0. Ekonomika pidpryiemstva : navch. posib. 5-te vyd., ster. K. : Vikar, 2008. 219 s. 31. Kostiakova A. A. Stratehichnyi upravlinskyi oblik: sutnist ta poniattia. Prychornomorski ekonomichni studii. 2019. Vyp. 39(2). S. 99-102. URL: http://nbuv.gov.ua/UJRN/bses_2019_39\%282\%29_21 (data zvernennia: 16.09.2020). 32. Fomina 0. V. Upravlinskyi oblik u torhivli : monohrafiia. Kyiv. nats. torh.-ekon. un-t, 2016. 468 s. URL: https://knute.edu.ua/file/MjExMzA=/624a6d7d9a739851810eef1d42fb84ce.pdf (data zvernennia: 16.09.2020). 


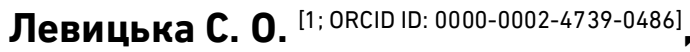
д.е.н., професор

${ }^{1}$ Національний університет водного господарства та природокористування, м. Рівне

\section{ЕКОНОМІЧНА ВИГОДА АКТИВІВ В ТРАНЗАКЦІЯХ СОЦІАЛЬНО ВІДПОВІДАЛЬНОГО БІЗНЕСУ}

Метою дослідження є: узагальнення на основі міжнародної та вітчизняної практики розвитку бізнесу факторів впливу на оцінку економічної вигоди активів підприємств 3 урахуванням вимог щодо соціально-економічної та екологічної збалансованості бізнесу; визначення та обґрунтування методичних та організаційних підходів щодо ідентифікації варіативних форм економічної вигоди, її оцінки. Підтверджено, що міжнародна практика підприємництва, враховуючи суспільну корисність бізнесу, виокремлює підвищення впливу на оцінку корисності підприємства результативність вирішення ним питань соціального забезпечення та екологічної безпеки як на рівні своєї діяльності, безпосередньо, так і в регіональному масштабі. Зазначене суттєво міняє роль і доповнює зміст поняття «економічна вигода»: оцінка потребує перегляду 3 урахуванням використання активу; серед елементів оцінки, крім економічних фінансових показників, з'являються нефінансові - якісні, що в цілому підвищує достовірність облікової інформації. Досліджено альтернативні форми економічної вигоди від використання виробничих ресурсів за результатами транзакцій вітчизняних підприємств в контексті політики збалансованого ведення бізнесу. Наведено міжнародну практику визначення фінансових результатів діяльності суб'єктів на основі аналітичного обліку елементів оцінки економічної вигоди, враховуючи їх вплив на вирішення питань економічного розвитку, соціального захисту та екологічної безпеки. В роботі уточнено критерії оцінки економічної та соціально-економічної вигоди, соціального ефекту.

Зазначене уможливить проведення результативного стратегічного планування як розрахунково-платіжної дисципліни, так і розвитку бізнесу на перспективу, що, безперечно, позитивно вплине на поступальний збалансований розвиток підприємництва в Україні.

Ключові слова: економічна вигода; потенціал корисності; підприємство; соціальна відповідальність; транзакція; збалансованість бізнесу; інтегрована система бухгалтерського обліку. 
Левицкая С. А. ${ }^{[1 ; 0 R C I D ~ I D: 0000-0002-4739-0486], ~}$ д.э.н., профессор

${ }^{1}$ Национальный университет водного хозяйства и природопользования, г. Ровно

\section{ЭКОНОМИЧЕСКАЯ ВЫГОДА АКТИВОВ В ТРАНЗАКЦИЯХ СОЦИАЛЬНО ОТВЕТСТВЕННОГО БИЗНЕСА}

Целью исследования является: обобщение на основе международной и отечественной практики развития бизнеса факторов влияния на оценку экономической выгоды активов предприятий с учетом требований по социально-экономической и экологической сбалансированности бизнеса; определение и обоснование методических и организационных подходов к идентификации вариативных форм экономической выгоды, ее оценки. Подтверждено, что международная практика предпринимательства, учитывая общественную полезность бизнеса, выделяет повышение влияния на оценку полезности предприятия результативность решения им вопросов социального обеспечения и экологической безопасности. Исследованы альтернативные формы экономической выгоды от использования производственных ресурсов по результатам транзакций отечественных предприятий в контексте политики сбалансированного ведения бизнеса. Приведены международную практику определения финансовых результатов деятельности субъектов на основе аналитического учета элементов оценки экономической выгоды, учитывая их влияние на решение вопросов экономического развития, социальной защиты и экологической безопасности.

Ключевые слова: экономическая выгода; потенциал полезности; предприятие; социальная ответственность; транзакция; сбалансированность бизнеса; интегрированная система бухгалтерского учета. 